\title{
Distal Bile Duct Cancer Clinical Distant Metastasis TNM Finding v8
}

National Cancer Institute

\section{Source}

National Cancer Institute. Distal Bile Duct Cancer Clinical Distant Metastasis TNM Finding v8. NCI Thesaurus. Code C134790.

A clinical finding about one or more characteristics of distal bile duct cancer, following the rules of the TNM AJCC V8 classification system as they pertain to distant metastases. 